\title{
A HOUSING REGIME UNCHANGED: THE RISE AND FALL OF FOREIGN-CURRENCY LOANS IN HUNGARY
}

AdRIENNE CSIZMADY, JÓZSEF HEGEDÜS AND DIÁNA VONNÁK ${ }^{l}$

\begin{abstract}
This paper analyzes the expansion and crisis of the foreign-currency (FX) loan market and responding mortgage-rescue programs in Hungary. We assess changes in the housing regime and illustrate the process through analyzing interactions between individual and institutional (state, financial institution, and municipality) strategies. We argue that the current, malformed housing regime has not changed significantly and remains vulnerable to similar events. This particular case offers insight into regional tendencies, while also explaining the reasons behind the escalation of the crisis in Hungary. We claim that the coping strategies and broader behavior of participants reinforced the disproportionate elements of the housing regime. Since 2015, housing policies have again relied on economic stabilization, now subsidized by the EU, that incentivize market solutions for private home ownership and disregard the experiences of past decades.
\end{abstract}

KEYWORDS: coping strategy, FX loans, mortgage, housing regime, Hungary

\section{INTRODUCTION}

Analyzes of Eastern European housing policies agree that the politicaleconomic transition of 1989-90 radically transformed the housing regime in the region. The mass privatization of public housing and the development of

\footnotetext{
1 Research for this paper was carried out in cooperation with the Centre for Social Sciences, Hungarian Academy of Sciences, and the Metropolitan Research Institute within the research project 'Families in Mortgage Crisis' (grant no. NKFIH - K109333). Corresponding author: József Hegedüs, scientific director of MRI; e-mail: hegedus@mri.hu. We would like to thank Júlia Király and Éva Várhegyi for their comments.
} 
housing finance institutions to support home ownership were key elements of the transition (e.g Roy 2008). Changing tenure has been modelled through typologies, most notably by Kemeny (1995), but such attempts stop at description and fail to address the different components (state, family, market) and ideologies that underpin certain models. Moreover, the characteristics of the emerging post-transition housing regime(s) remain under debate (e.g. Tsenkova, 2009, Hegedüs and Tosics, 1996, Hegedüs et al., 1996, Pichler-Milanovic, 2001, Lowe, 2003). In this paper, agreeing with Stephens (et al. 2015), we argue that it is crucial to embed typologies of housing systems into their ideological and socio-political context. In doing so, we follow Clapham's $(2002,2005)$ approach that argues that changes in housing regimes result from the interaction between policy measures and individual housing pathways, and offer an analysis of the Hungarian housing system throughout the 2008 economic crisis.

It is especially important to elucidate the socio-political context in analyzes of post-socialist housing systems, as they are products of a significant transition and volatile institutional histories. Moments of risk and crisis can expose their vulnerability and result in heavily politicized public debates about the distribution of responsibilities. The situation in Hungary was an especially strong example of this, its mortgage market having been among the hardest hit of all countries in and after 2008.

The housing system faced to two basic challenges in Hungary, and in the region overall. First, low-income households were forced into the lower end of the housing market, often into marginalized substandard housing, due to privatization. Second, as the former state housing subsidy and finance system disappeared, access to housing for middle-income groups was increasingly based on family support because of the lack of an affordable housing finance system. By 2000, after recovery from the transitional recession, many postsocialist countries made attempts to respond to these challenges. The pitfalls of the post-socialist housing regime were understood, aspirations existed to amend them. This involved a push to develop a market housing finance system, and plans to expand the social housing sector. However, political and economic interests related to the former were always more pronounced, often leaving the latter lower on the agenda. While the countries in the region experienced similar challenges, the timing and range of institutional solutions differed substantially (Hegedüs and Struyk, 2005, Aidukaite, 2014, Hegedüs et al. 2011, Dübel et al. 2006, Mandic and Cirman, 2012).

In Hungary, mortgage lending enjoyed political and fiscal support from the government, and the share of mortgages compared to the GDP rapidly grew between 2000 and 2004. After 2004, subsidized mortgages were replaced by foreign currency loans; the speed with which this market expanded in Hungary 
was comparable only to the situation in the Baltic States (Barel et al. 2009). The financial crisis of 2008 hit the Hungarian economy, and the household payment burden associated with foreign currency (FX) loans increased substantially, which caused political and social conflict. The Hungarian government introduced a series of different measures to "rescue" borrowers. This paper traces the process that led to the emergence of housing finance based on FX loan products, and provides an assessment of governmental programs that sought to alleviate the crisis and the reactions to these across the housing system. We argue that by 2015, when the economy recovered, the housing regime faced the same challenges as it did 15 years earlier. In spite of the institutional differences among the transitional countries, the basic challenges were still not addressed.

Having reconstructed the processes leading to the FX loan boom, we look at the ways households reacted to the emerging borrowing opportunities and how they coped with the hardship of the increasing payment burdens caused by the financial crisis. The research is based on qualitative interviews and was designed to reveal the varieties of household strategy both at the time loans were taken out and the time of the crisis. Through life course interviews we illustrate how the failure of the housing finance system forced households to accept compromised housing choices and family help, and to move into the informal economy, giving up dreams of home ownership. Although the material presented here is not meant to support generalization, it allows us to demonstrate the importance of the interplay of household behavior, and the policy of housing institutions. This contribution helps to demonstrate the need to move beyond institutional approaches. Highlighting the varieties of coping strategies and the choices of the most vulnerable segment of society adds nuance to understanding the crisis, now using hindsight, and taking the eventual outcomes of mitigation programs into consideration.

The paper is based on mixed-methods research. We offer a synthesis and reinterpretation of pre-existing data about mortgage development in Hungary, supplemented with expert interviews with key decision makers. When addressing household responses and the public discourse around the FX loan crisis, we rely on media analysis as well as 30 structured, in-depth interviews with FX debtors, and an additional nine further cases from parallel research projects. The sample is intentionally non-representative, its function being to elucidate the variety of household strategies and the interplay between policy measures and household behavior (Small, 2009). ${ }^{2}$

First, we explain the way we conceptualize housing regimes, offering a Stylized summary of the main features of post-socialist housing systems.

2 For the list of the interviews, see the Appendix. 
Afterwards, we describe the development of the mortgage market after 2000, and interpret the conflicts that emerged in connection to the financial crises. The final part of the paper focuses on the varieties of individual housing strategies, and the interaction between rescues programs and individual coping strategies. The second and the third part together offer a concise overview of the FX crisis in Hungary through which we hope to corroborate our methodological claim; i.e. the benefits of adopting an integrative approach when modelling housing systems in general.

\section{INTERPRETING HOUSING REGIMES: STRUCTURE AND INTERACTIONS}

\subsection{The sub-market matrix as an analytical tool for modelling challenges}

The political and economic transformation of 1989-90 brought about substantial changes in housing systems in Eastern Europe. There are three main approaches to understanding housing systems. Literature on housing in the 1980s was defined by the housing provision approach that focused on the embeddedness of housing (e.g. Ball and Harloe 1992). Here, housing forms represent modes of production and distribution, a view based on structuralist assumptions, hence they are socio-politically determined. Institutional economics remained a dominant approach as well (Matznetter, 2002, Matznetter and Mundt, 2012, Malpass, 2008, Lunquist, 1990, Fitzpatrick and Stephens, 2014); this places significantly less emphasis on the socio-political context, or causal links between these and institutions. Finally, Kemeny's tenure typology (1995; Kemeny et al. 2005) and followers focused on the structure of the rental sector in a given country and introduced a division between universal and residual sections. In Kemeny's model, socio-economic structures and mainstream ideologies are reflected in the housing system.

We find institutionalist approaches to be insufficient for addressing the broader context and consequences of housing regimes. In order to move beyond this, our approach builds on recent work by Hegedüs (2018) that departs from a combination of the tenure and provision approach, developing a typology of housing provision based on a sub-market matrix. Our argument is in line with that of Barlow and Duncan (1988) who criticized the one-sidedness of the tenure approach and instead combined ownership form with the form of production in their typology. Arguing that these are insufficient for addressing the social consequences of respective housing regimes, we suggest following 
Polanyi's argument about the role market, redistribution and reciprocity play as integrative mechanisms of social and institutional systems (Polanyi 1944). Our approach hence conceptualizes the provision dimension of housing systems through these, with an additional category of exclusion, to better theorize the limits of integration. In terms of the forms of tenure, we have followed the mainstream approach.

Table 1. Framework for the comparative analysis of housing regimes, with international examples

\begin{tabular}{|c|c|c|c|c|}
\hline & & \multicolumn{3}{|c|}{ Tenure forms } \\
\hline \multirow{5}{*}{ 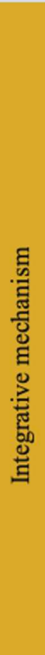 } & & $\begin{array}{l}\begin{array}{l}\text { Social rental } \\
\text { housing }\end{array} \\
\end{array}$ & Private rental housing & $\begin{array}{l}\text { Owner-occupied } \\
\text { housing }\end{array}$ \\
\hline & $\begin{array}{l}\text { State/social } \\
\text { integration }\end{array}$ & $\begin{array}{l}\text { "A": Council } \\
\text { housing, rental } \\
\text { cooperatives, }\end{array}$ & $\begin{array}{l}\text { "B": Social rental } \\
\text { housing agency, } \\
\text { significant housing } \\
\text { subsidy models }\end{array}$ & $\begin{array}{l}\text { "C": Singapore } \\
\text { model, Land Trust, } \\
\text { Spanish/Portuguese } \\
\text { subsidized private } \\
\text { ownership }\end{array}$ \\
\hline & $\begin{array}{l}\text { Market } \\
\text { integration }\end{array}$ & $\begin{array}{l}\text { "D": Social } \\
\text { landlords enter the } \\
\text { market } \\
\text { (Netherlands) }\end{array}$ & $\begin{array}{l}\text { "E": Typical private } \\
\text { rentals (istitutional or } \\
\text { individual landlords) }\end{array}$ & $\begin{array}{l}\text { "F": Typical private } \\
\text { ownership }\end{array}$ \\
\hline & $\begin{array}{l}\text { Reciprocative } \\
\text { (family and } \\
\text { friends) }\end{array}$ & $\begin{array}{l}\text { "G": Sub-tenants } \\
\text { move into social } \\
\text { rental housing based } \\
\text { on favor }\end{array}$ & $\begin{array}{l}\text { "H": Favor-based } \\
\text { rentals, special financial } \\
\text { agreements }\end{array}$ & $\begin{array}{l}\text { "I": Housing provided } \\
\text { as a favor (e.g. } \\
\text { between relatives) }\end{array}$ \\
\hline & $\begin{array}{l}\text { Exclusion, } \\
\text { homelessness }\end{array}$ & $\begin{array}{l}\text { "J": Homeless } \\
\text { services }\end{array}$ & $\begin{array}{l}\text { "K": Illegally occupied } \\
\text { housing }\end{array}$ & $\begin{array}{l}\text { "L" Sub-standard } \\
\text { housing }\end{array}$ \\
\hline
\end{tabular}

Source: authors' compilation

The housing regime is an interpretation of a housing system according to the logic of the sub-market matrix, where differences between regimes emerge as the result of the structure of the matrix and the connected legal and fiscal regulations, as well as widely shared political ideas related to housing. Housing regimes are inseparable from their surrounding contexts: economic development, the structure of the labor market, welfare regimes, and the redistribution of wealth. The sub-market matrix and the definition of housing regimes together allow for a more comprehensive understanding of the social consequences of housing systems. For example, state intervention could be efficient through 'B' 
or ' $\mathrm{C}$ types of provision which both use non-public ownership models to achieve public goals.

Transition was conceptualized as the approximation of the housing regimes of former socialist countries to regimes found in Western European countries (Kemeny and Lowe 1998). To illustrate the trajectory of post-socialist housing systems, we use a simplified figure (Figure 1), wherein sub-market matrices are characterized by a solid home-owner sector and a large social and private rental stock. These could loosely be called Western European housing systems, with the caveat that housing systems are very different within that region too, due to divergent historical and political ideological trajectories. As such, this model represents an ideal type rather than the existing reality. ${ }^{3}$

In contrast to this, Figure 2 indicates the weak points of the post-socialist housing system. The most significant difference is the virtual lack of a social housing sector; i.e., regulated forms of housing integrated by the state that offer a safe and satisfactory option for the lower-income social strata. Market solutions for housing acquisition by the middle class that can operate without significant state subsidies are also lacking because of the underdevelopment of the housing mortgage system.

As in other countries in the region, two major shifts took place in Hungary after 1990. On the one hand, the proportion of state-owned housing stock fell from 21\% to 3\% between 1990 and 2001 (Székely, 2011). The stock that remained in state ownership was usually of worse quality. On the other hand, state subsidies and the housing finance model were diminished. The above-outlined issues (i.e. the lack of social housing programs and affordable housing finance) represented the most important challenges at the beginning of the new millennium. Some programs aimed at increasing the social sector and the market-based finance system at the cost of the owner-occupied-reciprocal type (type 'J' in Table 1). The high share of type ' $\mathrm{J}$ ' provisions meant the predominance of cash-based transactions and reliance on the family, a situation which is described in the new literature as a 'familial housing finance system' (e.g. Bohle 2018; Stephens et al. 2015).

3 Several attempts have been made to conceptualize individual differences in Western European housing systems. Kemeny's approach, which distinguishes between residual and integrated rental models based on the relationship between social and market rental (Kemeny 1995, Kemeny et al. 2005), and Haffner's analysis of rental systems according to the legal, financial, distributional "gap" between them (Haffner et al. 2009), are powerful explanatory tools. 


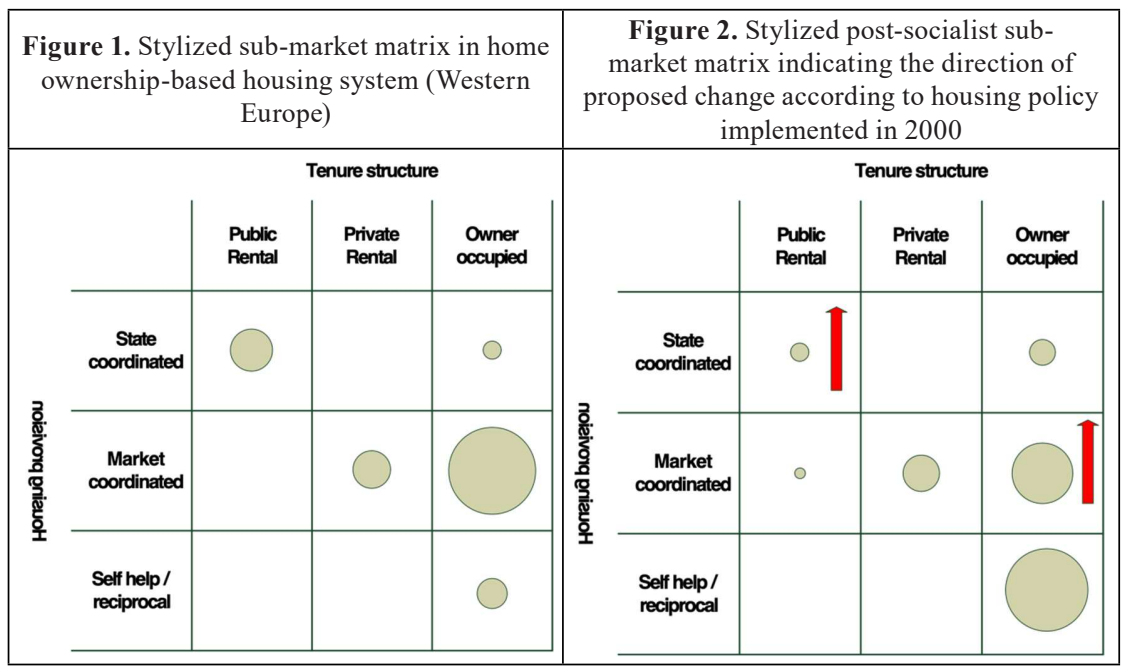

Source: authors' compilation

By the time the economy was consolidated in Hungary in around 2000, these challenges were obvious to policy-makers, yet their political currency was far from equal. Political and budgetary support for social housing programs remained insufficient, while the portfolio-related decisions of the home-owning upper-middle class remained decisive. The risks associated with private rental remained high thanks to bad regulation, which curtailed growth. As elsewhere in the region, housing was not fully financialized in Hungary; still, housing finance programs retained their importance everywhere, albeit with diverse institutional solutions and mortgage lending volume (Hegedüs and Struyk, 2005, Stephens et al. 2015).

\subsection{Institutional and household strategies}

The behavior of households and institutions in the housing market can constitutes the dynamic element of the housing regime in the matrix we use. We second Clapham in stating that "the impact of policies can only be gauged through an understanding of the complex interplay between organizational policies and their implementation and the way that applicants for housing react in the light of their perception and attitude" (2002: 57). Housing regimes change when households and institutions react to economic, political and financial circumstances, shaped by prevailing norms and ideologies. Their decisions bring about changes in the sub-market matrix, and in housing solutions, as 
represented in the cells in Table 1. It is therefore important to assess the key elements in institutional and individual housing-related decision making. Household pathways highlight the importance of alternatives: decision-making mechanisms and motivations vary widely (Lin 2012).

Strategies related to career, pension, savings, and consumption patterns are intimately linked to housing decisions, thanks to the role housing plays as an asset in households' portfolio and in welfare systems (e.g. Ronald, 2008; Ronald and Elsinga, 2011). As crisis in any domain of life has repercussions for the rest, such correlations should be factored in when modelling housing strategies and housing systems. Familiaism is especially important in housing regimes when access to loans is curtailed. Such support is not predictable and reliable, and it often comes with risks of its own - it should form an integral part of our understanding of post-socialist housing regimes.

Like that of households, the behavior of institutions - be they government organizations, banks, or real estate agencies - is shaped by the fiscal, institutional and policy context they operate in. The mission of institutions might be at cross purposes with their political and financial targets. For instance, a key mission of local governments is supporting low-income residents with social housing options, yet financial constraints and electoral strategies often push the former to rid themselves of difficult tenants. NGOs committed to social initiatives also have to juggle their priorities, while institutional survival and the need to pay employees fairly might strain their budgets at the expense of core mission (Le Grand, 2003).

Finally, households and institutions operate in an unpredictable environment. With the advent of global capitalism and rapid urbanization, economic hazards and crises have become intrinsic to economic development; contemporary European societies are risk societies (Beck 1992, Giddens 1999). Economic recession, unpredictability, and the transformation of the role of the state in Eastern Europe resulted in an increase in the importance of informality; this concerns economic activities as much as labor arrangements, and includes strong reliance on family and friends (Pavlovskaya 2004, Ries 1997). These complexities have to be accounted for when drawing up a full picture of housing regimes. 


\section{MORTGAGE BOOM AND ECONOMIC CRISIS}

\subsection{The development of the mortgage market between 2000 and 2015}

As noted above, policy makers and decision makers understood the contradictions and weaknesses of the post-socialist housing regime in Hungary. No official housing strategy was laid out by the government, but inside sources indicate the following were present; suggestions for an increase in social housing sector, the construction of new stock for rent, and supporting the construction and purchase of privately owned homes with mortgages (see Növekedéskutató Intézet 1999, GM 2000, Otthon Európában 2003). Similar trends characterized housing policies across the region. In Hungary, three stages can be identified in housing politics between 2000 and 2015 .

\section{Stage 1: Subsidized loans (2000-2004)}

The first Fidesz government (1998-2002) launched two programs after 2000: one was designed to increase the social housing stock; the other targeted the mortgage market. These were clearly designed to compensate for the abovedescribed discrepancies, although the strategy was never set out in a policy document. Governmental and institutional interest groups substantially diverted this agenda: the key conflict took place between banks and the construction lobby, with the triumph of the former (Hegedüs 2006). The council housing program did not amount to a breakthrough in social housing, but it still demonstrated that local governments were capable partners in social housing issues if given appropriate fiscal means. However, throughout its four years of operation, this program increased the number of social housing units by less than the number of units that left the sector in the years of "trickled" privatization between 1998 and 2004 (Hegedüs 2011: 120). Moreover, the financial burden of social housing was placed on local governments themselves, which made it virtually impossible to foster long-term interest in supporting social housing programs on their side ${ }^{4}$.

Government politicians saw mortgage subsidies as the cornerstone of their re-election strategies and promoted them to significantly broaden support. (Várhegyi 2002). Mortgage subsidies became so successful that the amount that

4 It is worth noting that other countries in the region ran into similar problems. The most successful program was developed in Slovakia, where loan regulations prescribed for owners of social housing financially feasible rent payments (Hojsik, 2013). 
was lent grew more than seven-fold between 2000 and 2003, which turned out to be unsustainable from a fiscal point of view. The newly elected Socialist-Free Democrat coalition maintained subsidies for the next two years. The proportion of the value of mortgages in relation to GDP grew from $1.1 \%$ to $10 \%$ between 2000 and 2004 while construction boomed and prices rose, but not to the extent that led to a price bubble (Table 2).

Table 2. The housing market: key indicators, 2000-2015 (Source: KSH, FHB price index, $M N B$ )

\begin{tabular}{|c|c|c|c|c|c|c|c|}
\hline & $\begin{array}{c}\text { Number of } \\
\text { transac- } \\
\text { tions (new } \\
\text { and used) }\end{array}$ & $\begin{array}{c}\text { Number } \\
\text { of housing } \\
\text { units in use }\end{array}$ & $\begin{array}{c}\text { Number of } \\
\text { con- } \\
\text { struction } \\
\text { permits }\end{array}$ & $\begin{array}{c}\text { FHB price } \\
\text { index } \\
\text { deflated } \\
\text { according } \\
\text { to year } \\
2000=100\end{array}$ & $\begin{array}{c}\text { Mortgages } \\
\text { (billion } \\
\text { HUF) }\end{array}$ & $\begin{array}{c}\text { Proportion } \\
\text { of FX loans } \\
\text { in the loan } \\
\text { market }\end{array}$ & $\begin{array}{c}\text { Proportion } \\
\text { of value of } \\
\text { mortgages } \\
\text { to GDP }\end{array}$ \\
\hline 2000 & 183950 & 21583 & 44709 & 100 & 192 & $1 \%$ & $1,4 \%$ \\
\hline 2004 & 171678 & 43913 & 57459 & 135 & 2106 & $1 \%$ & $10,0 \%$ \\
\hline 2008 & 154097 & 36075 & 43862 & 125 & 6507 & $63 \%$ & $23,9 \%$ \\
\hline 2012 & 87957 & 10560 & 10600 & 88 & 5752 & $68 \%$ & $20,0 \%$ \\
\hline 2015 & 134101 & 7612 & 12515 & 99 & 4691 & $64 \%$ & $13,7 \%$ \\
\hline
\end{tabular}

Source: authors' compilation

\section{Stage 2: The expansion of the FX loan market (2005-2008)}

The Socialist-Free Democrat coalition that came to power in 2002 gradually decreased loan subsidies, bringing about the perceived threat that the housing loan market would collapse. Foreign currency loans, first introduced under the preceding right-wing government, seemed to offer a cheap alternative, and thereby a way out. The National Bank held HUF interest rates high because of the budgetary deficit and the ability to finance state debt. The difference between the interest rates for HUF loans and FX loans, coupled with less institutional support for HUF loans, meant that FX loans offered cheaper instalments for clients. The most popular of these were home equity loans backed by real estate, wherein the target of the loans was not restricted. Literature from the time reveals that experts were aware of the risk posed by fluctuating interest rates, but estimated this to be low (Dömötör 2011, Schepp 2008). FX loans quickly came to dominate the mortgage market: their share reached $63 \%$ of housing- 
related mortgages by 2008. Many factors played a part in this boom: wages increased, instilling optimism in many; competition between banks led to a growing network of advisers and agents. During the same period, the social rental program was cut due to fiscal pressure. The rent support program that replaced it failed, as it did not consider owners' expectations appropriately (Hegedüs 2006: 95-96). Plans to support entrepreneurial construction programs for rented housing also came to a halt, since the risk of managing units in the insufficiently regulated private rental market was higher than the expected benefits.

\section{Stage 3: Economic crisis and the responding programs (2009-2015)}

The economic crisis reached Hungary in autumn 2008. Roughly one million households were under growing financial pressure mainly due to FX loans, turning mortgages into one of the most controversial, hotly discussed topics between 2008 and 2015. Housing politics was dominated by the issue of the foreign currency credit crunch and debates about the measures needed to alleviate it. Until 2010, programs that were introduced involved the customary tools of crisis management. After 2010, however, the new government introduced radically new and unorthodox measures, made possible domestically by the two-thirds electoral majority that propelled them into power. Internationally, it was crisis and the consequent pressure over the EU that allowed unorthodox measures to go unsanctioned.

Inconsistent policies of the time suggest a lack of comprehensive planning; several suggestions were proposed to mitigate the social cost of the crisis and to stabilize the economy. After 2010, radical steps were made in the welfare system: unemployment programs were replaced by a controversial public work program (Szőke 2015), while housing maintenance and debt management support was cut. Social programs and the responsibility for allocating resources for them were pushed down to the level of local government.

\subsection{The political economy of the mortgage crisis}

Economic growth between 2004 and 2008 meant that all sides (the government, banks, households, the construction and development sector, agents, etc.) benefitted from the expanding mortgage market, even when the risks and profits were distributed in a starkly uneven fashion. General growth made these inequalities palatable politically: there was no sharp conflict. The 
unequal distribution of costs and risks was a result of the institutional landscape and power structures, and was made visible only with the deepening crisis.

All actors involved agreed that the affordability of FX loans made them attractive, and that the fluctuating exchange rate posed only a moderate risk. Banks secured their position with unilateral contracts, allowing them to increase interest rates, and by real estate collateral; debtors could repay unless their circumstances changed radically; the state did not have to step in with subsidies, and financial regulatory bodies did not have to intervene beyond declaring textbook risks. ${ }^{5}$ These actors pieced together a shared understanding about housing finance and the interpretation of the housing finance system, its risks, functions, and responsibilities that formed the basis and context of actors' strategies.

Information asymmetry posed a crucial problem. Debtors often lacked the oversight necessary to make realistic risk assessments; this made them vulnerable. This was not merely a question of financial literacy, but also of insufficiently transparent contracts and the controversial strategies of agents and financial advisers. In relation to the banks, the problem of moral hazard may be raised; namely, the expectation of the former that in the case of systemic crisis the state would need to support debtors anyway thus some of the risks associated with liberalized lending regulations would be pushed onto the state. This led to transparency on paper only; both information asymmetry and the banks' calculation of moral hazard occurred in power structures that exposed the most vulnerable segment to disproportionate risk.

The 2008 crisis hit Hungary especially hard thanks to macroeconomic imbalances, irresponsible fiscal policy, and growth in the level of consumption that was based on mortgage lending rather than economic fundamentals. Due to fluctuating exchange rates, debtors' instalments grew to an extent that many could not pay (Dancsik et al. 2015). Unemployment increased, and wages decreased. The government cut welfare spending, including housing support, while the banks' strategy of increasing interest rates and service costs further accentuated social problems. The shared understanding broke up, replaced by competing strategies of allocating responsibility and blame. Without consensus, the crisis was maintained by competing groups that pushed for their own respective interests; this inflated the costs of solving it. Neither economists not lawyers were undivided.

5 The National Bank strengthened the currency using high-interest-rate-based policies. Director Járai publicly equated a strong currency with a strong economy. In the euphoria that followed EU accession, it would have been unfeasible to argue against euro bank loans anyway (Várhegyi 2010). 
Each group was heterogeneous, but overall we could say that the cost of the credit crunch could have been distributed between the state (i.e. tax-payers), bank shareholders, bank client, and debtors. ${ }^{6}$ As consensus was lacking about the responsible parties, cost allocation became a political game. Expert's views can be classified into three main positions:

1. Debtors are responsible: there is no need to 'rescue' debtors as they should have understood the risks inherent in the contracts they signed. Debtors subscribed to the risk of fluctuating exchange rates, the benefits of which they enjoyed when HUF rates were high, hence it is unreasonable to take over their costs.

2. Responsibility should be shared: The cost of FX lending is distributed across all participants, so social and financial costs should be distributed fairly.

3. Debtors are not responsible: FX lending was irresponsible in the first place, and abused consumers with non-transparent contracts and insufficient information. Debtors should be compensated and costs taken over by banks and the state.

The first position was articulated most clearly by Csillag and Mihályi (2011), who did not see the need for rescue programs. The former argued that competent economic policies would strengthen HUF rates again, and this would eliminate the need for intervention. Besides, these events would help to shake up a stagnating housing market. Social considerations also played a part in their reasoning: they thought that the bulk of FX debtors came from the middle class; targeting more vulnerable debtors would thus be difficult. Many analyzes supported this assessment; for example, Gáspár and Varga (2011) underestimated the number of households involved and postulated rapid improvements within one or two years. Even the evaluation reports of the National Bank of the time thought the crisis was manageable, and many in the social sector were hesitant to advocate for rescue programs.

The second position was shared by many analyzes that tried to juggle responsibilities among various players. The 2010 parliamentary committee that was tasked with an evaluation wrote a balanced analysis that collected the arguments according to which responsibilities could be determined (OGY 2012). The preceding and following discussions did not result in an expert consensus, but contributed to a fuller understanding of the contributory factors. Surányi $(2010,2015)$ emphasized the role of bad fiscal policy as well as the National

6 Many different technical solutions may be formulated within this gross simplification but this would require a closer evaluation of each program, which is beyond the scope of the paper. 
Bank; however, he expected steps to be taken that would have gone beyond the legal and theoretical mandate of the National Bank, as others pointed out (Pete 2010, Obláth 2010). Discussions mostly centred around the role of past governments (Fidesz 1998-2002, Socialist Party-Free Democrats 2002-10), the National Bank, individual banks, and debtors. Disagreements remained prominent, but the basic proposition that costs should be shared among all actors who were involved was common.

The third position gained real prominence upon statements made by prominent economist, banking professional and green party politician Péter Róna (2013), who declared FX loans to be "faulty products." Responsibility was to be shared by banks and insufficient state regulation. Róna's interpretation relied on a specific definition of loans that denied the risks inherent to lending, that hinge on macroeconomic circumstances. The 'faulty product' concept was more of a political ideological tool, a vehicle of party politics than a sound economic concept. Róna's views were picked up by the media and anti-bank movements (Szabó 2018)?

Rescue-related problems were due to certain elements of the above interpretation. Bajnai's government, formed after the resignation of PM Gyurcsány in 2009, subscribed to the first position. The incoming Fidesz government relied on various versions of the second, but more in its actual policies than its public communication, while social movements organized themselves around the third position.

\section{HOUSING STRATEGIES AND THE HOUSING REGIME}

\subsection{Individual housing loan strategies during the expansion of the loan market}

Economists thought that the decade-long recession in the 1990s had led to impatience among consumers, and this accounted for the huge demand for housing loans in the early 2000s (Tóth and Árvai 2001). Affordable loans not only contributed to housing demand, but opened the way for investment and consumption strategies too. Consumer credit that was used to facilitate the purchase of goods without depleting savings, and home-equity loan made such decisions even easier. Unexpected medical costs were often paid for with such loans (INT 35). Such strategies put households in a financially untenable condition.

\footnotetext{
7 Róna's policy proposals were a lot less radical than his statements in public discussions and the media.
} 
Housing property is not only a form of consumer goods, but also a means of saving and accumulation, the significance of which grows with age (Ando and Modigliani 1957). Theorists of asset-based welfare stress the importance of housing properties in accumulating savings (Doling and Ronald 2010). Low interest rates can be avoided by purchasing real estate, and the accumulated resources may be used in old age or for assisting children with home acquisition. With an appropriate personal contribution, it was therefore common to borrow for the purpose of accumulation and lease the housing units; with a 20-30\% down-payment, rent payments could cover instalments.

Private entrepreneurs often took out loans to make investments using real estate collateral. This affected the broader housing situation of the household, especially when the economic crisis and worsening currency rates started to have an impact on the labor market. In the worst case, failed investments led to the loss of homes, and with that, housing security issues.

The spread of free-use FX loans attracted many lower income households who sought to compensate for household deficits with loans. FX loans were often used to pay for more expensive, preexisting loans; in these cases, they should be seen as means of short-term debt settlement. Many HUF loans were turned into FX loans, which simply postponed the moment of bankruptcy in many cases without addressing the structural deficit.

The motivations behind the credit boom were amplified by the contradictions of the economic regime and the welfare system, as these increased the risks households needed to take. For lower-income households especially, the fact that the criteria of creditworthiness changed meant an unprecedented chance for home ownership, which was often the only satisfactory solution. Three alternatives existed for such households:

- Private rental, which left individuals vulnerable due to under-regulation and the black market (Hegedüs et al., 2014).

- Substandard and/or peripheral housing choices, such as converted holiday houses, property in depressed areas, etc.

- Intergenerational cohabitation, like living in flats owned by friends or family. 
Table 3. Motivation for and key factors behind the credit boom

\begin{tabular}{|c|c|c|}
\hline Motivation & Key factors & $\begin{array}{c}\text { Interview } \\
\text { number }\end{array}$ \\
\hline $\begin{array}{c}\text { Housing } \\
\text { consumption }\end{array}$ & $\begin{array}{c}\text { Private rental and intergenerational cohabitation were } \\
\text { considered increasingly unacceptable solutions. Private } \\
\text { home ownership was seen as superior compared to the } \\
\text { alternatives and cheaper in the long run. }\end{array}$ & $\begin{array}{c}\text { I1, I2, I3, I26, I5, } \\
\text { I6, I13, I16, I18, } \\
\text { I19, I20, I21, I24 }\end{array}$ \\
\hline Consumption & $\begin{array}{c}\text { Economic recession in the 1990s and decreasing wages } \\
\text { contributed to general consumer frustration: demand for } \\
\text { cars and goods had increased by the time "cheap loans" } \\
\text { arrived. }\end{array}$ & $\begin{array}{c}\text { I10, I11, I15, I16, } \\
\text { I17, I28 }\end{array}$ \\
\hline Saving & $\begin{array}{c}\text { The pension system was considered insufficient and } \\
\text { unreliable, thus investing in real estate was seen as a safer } \\
\text { way of accumulation for the middle class. }\end{array}$ & $\begin{array}{c}\text { I2, I3, I0, I15, I20, I24, I25, } \\
\text { I30 }\end{array}$ \\
\hline Investment & $\begin{array}{c}\text { Labor market restructuring brought an increase in the } \\
\text { number of small entrepreneurs, often motivated by the } \\
\text { desire to evade tax. In the case of real small enterprises, } \\
\text { shortages of capital were compensated for using loans } \\
\text { backed by real estate collateral. }\end{array}$ & $\begin{array}{c}\text { I3, I11, I30, I31, } \\
\text { I36, I37 }\end{array}$ \\
\hline $\begin{array}{c}\text { Debt } \\
\text { settlement }\end{array}$ & $\begin{array}{c}\text { Loans borrowed for debt settlement indicate failures } \\
\text { of the welfare system. These were normally related to } \\
\text { unsustainable problems at the household level. }\end{array}$ & I10, I15, \\
\hline
\end{tabular}

Source: authors' compilation

It is no wonder then, that after years of renting and existing in conflict-ridden cohabitation (I22) or crowded flats many people virtually escaped into home ownership (I32). Social expectations provided a further push as renting is usually seen as a temporary, inferior solution that precedes appropriate solutions; i.e. home ownership. Renting was considered a waste of money (I16, I22), as rental payments were comparable to monthly instalments (see also Hegedüs and Teller 2007, Hegedüs and Szemzö 2015). Jointly, the housing regime and these expectations pushed many households with an insufficient protective network and financial assets, etc. towards borrowing (I5, I19).

As creditworthiness was judged in an increasingly lenient fashion, local governments and construction permits were easily obtained, and credit agencies lacked proper regulation, irregularities came to characterize FX loan lending. One important example of systemic exploitation occurred in relation to a scheme in the Avas estate, Miskolc, ${ }^{8}$ while we recorded another comparable example from a regional industrial capital in Western Hungary, where a Roma family with eight children signed a mortgage contract for 7.8 million HUF,

$8 \mathrm{http}: / /$ magyarnarancs.hu/kismagyarorszag/vissza-a-gettoba-miskolc-kisopri-afeszekrakokat-90100 
although they lacked savings and had never met either representatives of the city council, or the bank (I32). To sum up, from the beginning of the 2000s, due to the accentuation of competition between banks and deflated interest rates, wider and wider social strata had access to loans. This offered the possibility of home ownership to households for whom this had not earlier been possible. We argue that many entered the widening housing loan market for whom the risks were too high.

In the first years of the credit boom, most debtors came from higher income households (Bethlendi 2009). Those in the top 20\% according to income were five times more likely to take out loans, and in amounts almost $20 \%$ more than the average (Hegedüs 2006: 85). After 2004, the social composition of debtors changed, with growth in the proportion of people who would not have been creditworthy for HUF loans, or only for much smaller amounts. Data from 2011 show that $8.1 \%$ of those with housing-related mortgages could be classified into the lowest-earning $10 \%$, and $14.1 \%$ into the top $10 \%$ (KSH 2011). With freeuse mortgages, the situation was almost the opposite: $18.2 \%$ of borrowers came from the lowest earning strata, and 7.9\% from the highest $10 \%$ (ibid.).

Lower income households chose home ownership in circumstances when, in a well-functioning housing regime, social housing or housing cooperatives would have been more appropriate choices for them. Their decisions were corroborated by the virtual absence of real alternatives in the social or private rental sector. In the final sections of the paper, we focus on the strategies of this most vulnerable stratum, relying on qualitative evidence.

\subsection{Dynamics of rescue programs ${ }^{9}$}

The effects of the 2008 crisis permeated the mortgage system only slowly. Late payments became more common: between December 2008 and December 2009 , the proportion of contracts associated with overdue payments of more than 90 days rose from 3.5\% to 7.5\% (MNB 2010). In Latvia, the proportion exceeded $10 \%$ by 2009 (Erbenobva et al., 2011).

The Socialist/Free Democrat Gyurcsány government did not address this situation with mitigation programs; political willingness and financial resources were both lacking. The government subscribed to the first approach, pushing responsibility exclusively onto "irresponsible" debtors. Households started to realize the magnitude of the problem as instalments skyrocketed thanks to the fluctuation in interest rates as well as increases in the interest rates that

9 This part of the paper is based on Csizmady and Hegedüs, 2016. 
banks introduced to factor in increasing risks. Banks utilized the leeway that unilateral contracts afforded them, expecting state intervention in case of mass bankruptcy.

In 2010, when the right-wing Orbán government came to power with a supermajority, engineering a confrontation with banks fit the former's unorthodox goals of social transformation (Várhegyi 2018). This confrontation allowed them to intervene in the bank sector - and to push for a share of more than $50 \%$ for so-called domestically owned banks. The government accepted the second interpretation (see earlier) which left them with ample room to fine-tune economic policies in service of political goals. In public communication they often adopted the positions of the radical opposition (i.e. the third interpretation), but in their programs they followed a different strategy.

Housing politics were dominated by the management and mitigation of social conflicts caused by the credit crunch. The key framework was laid out in a 2011 action plan. ${ }^{10}$ Although the government pulled rank in negotiations, it took the reactions of the market into consideration. However, the aims of many programs reached beyond housing issues (for example, intervening in positions of power among banks,${ }^{11}$ the consolidation of the finances of the middle class, pacification of the poorest stratum, and the neutralization of political movements).

One of the most controversial, unorthodox programs was the early repayment program (Table 4). This allowed borrowers to repay in a single instalment at a better exchange rate between September 2011 and February 2012 (PSZÁF 2012). Early repayment targeted more affluent debtors, creating huge losses for banks while disregarding issues of fair redistribution and social justice, and reducing the potential of political mobilization. Eighteen percent of debtors used this opportunity (ca. 170 thousand contracts). This created 300 billion HUF of losses, or 1.7 million HUF per debtor. The government weighed in to incentivize early repayment: savings banks were ordered to offer loans, the tax office did not examine the origins of repayments, state organizations and companies were encouraged to lend to their employees, banks were threatened with repercussions if they sabotaged the process.

The least controversial, most successful program was offered by the National Asset Management Ltd. The social housing enterprise was supported by an

10 In decree LXXV (2011) key elements of the rescue programs were present, such as the regulation of forced sales, an exchange rate cap, and conversion to HUF. However, repeated amendments of the law indicate uncertainty and a lack of long-term planning.

11 It is beyond the scope of this paper to discuss the compromise created between banks and the government, but it is likely that the government exploited existing conflicts between banks and played a role in weakening OTP, the largest bank, while supporting FHB and savings banks, as was revealed during the conflicts that followed the introduction of the early repayment policy. 
alliance of banks. Through NAM, the state bought mortgages, turning collateral housing units into rental constructions and allowing former owners to stay on as tenants, paying a fixed, heavily reduced rent. Thirty-six thousand units were included in the program, seven times the amount expected in the initial plan. Eligibility criteria and conditions changed repeatedly as the program grew. It is difficult to estimate the overall cost of the program, but it is thought to have been around 150 billion HUF, or 4.2 million per household.

Those whose status was in-between that of the most vulnerable and the affluent were unable to take advantage of the early repayment program or the NAM as they lacked savings for the former and did not fit the strict criteria of the latter. By 2018, the number and proportion of defaulters had decreased, but the reason for this was the outsourcing of cases to winding-up institutions.

Table 4. Governmental and non-governmental programs aimed at supporting FX loan debtors

\begin{tabular}{|c|c|c|c|c|c|}
\hline \multirow{3}{*}{$\begin{array}{l}\text { Social } \\
\text { strata }\end{array}$} & \multicolumn{3}{|c|}{ Government programs } & \multirow{3}{*}{ Banks } & \multirow{3}{*}{$\begin{array}{c}\text { Social } \\
\text { movements, } \\
\text { alternative } \\
\text { programs }\end{array}$} \\
\hline & \multicolumn{2}{|c|}{ Aimed at a specific group } & \multirow{2}{*}{$\begin{array}{l}\text { Aimed at the } \\
\text { whole of society }\end{array}$} & & \\
\hline & successful & failed & & & \\
\hline $\begin{array}{l}\text { Upper } \\
\text { class }\end{array}$ & $\begin{array}{l}\text { Early repayment } \\
\text { (2011) }\end{array}$ & \multirow{2}{*}{$\begin{array}{c}\text { National } \\
\text { Bank civil } \\
\text { bank (2012) }\end{array}$} & \multirow[b]{3}{*}{$\begin{array}{l}\text { Compensation of } \\
\text { debtors (2014) } \\
\text { Conversion to } \\
\text { HUF loans (2015) }\end{array}$} & Restructuring & \multirow{3}{*}{$\begin{array}{c}\text { Court cases, } \\
\text { protests, } \\
\text { NGO } \\
\text { interventions } \\
\text { (continuous) }\end{array}$} \\
\hline $\begin{array}{l}\text { Middle } \\
\text { class }\end{array}$ & $\begin{array}{l}\text { Exchange rate } \\
\text { cap (2012) }\end{array}$ & & & & \\
\hline $\begin{array}{l}\text { Working } \\
\text { class }\end{array}$ & $\begin{array}{l}\text { National Asset } \\
\text { Management } \\
\text { Ltd. (2012), } \\
\text { moratorium } \\
\text { on evictions } \\
(2009-14)\end{array}$ & $\begin{array}{l}\text { Ócsa (2014), } \\
\text { Personal } \\
\text { bankruptcy } \\
(2015)\end{array}$ & & $\begin{array}{l}\text { Involving } \\
\text { credit } \\
\text { managers } \\
\text { (after 2015) }\end{array}$ & \\
\hline
\end{tabular}

Source: authors' compilation

Besides the above-described two programs, several other government interventions were introduced. The cost of capping the exchange rate was paid by banks; this was less successful than early repayment, even though it benefited banks too. A moratorium on evictions was introduced, then maximum eviction quotas and obligatory currency conversion; laws concerning personal bankruptcy were in the making for years, only to represent a solution in less 
than 1000 cases. These programs were subject to heated policy debates and most changed repeatedly, partly due to adjustments, partly thanks to changes in the strategies of the actors involved.

The proportion of households with housing loans grew from $7.5 \%$ in 2000 to 15\% in 2007 (Medgyesi 2008); 19\% of households had mortgages in 2010 (KSH 2011). It is difficult to assess the number of households involved in different programs, but we estimate ${ }^{12}$ that $60 \%$ of those with mortgages (i.e. 850 thousand households) adapted without significant loss. Around $40 \%$ of them lost out, many through forced sales (see Figure 3).

Figure 3. Proportion of households participating in various programs (estimation)

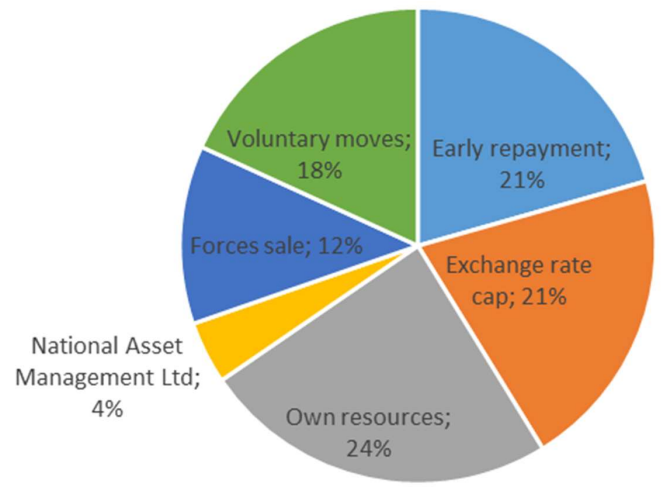

Source: authors' estimation

Debtors' plight was a central theme of public discourse between 2010-2016. Thanks to the often changing programs and an uncertain policy landscape, many households hesitated to take steps; it was far from obvious when it was best to opt for a program when new solutions were being introduced and delays could result in more advantageous solutions. Many kept waiting for better alternatives. Uncertainty was fostered by social movements that ignited hopes that eventually prove false; their moderate social base was insufficient, and their claims that lacked legal or economic feasibility. Lawsuits were started in this combustible atmosphere; the government lacked direct influence over these, despite its supermajority. Mass lawsuits could have led to the government losing

12 This estimation is based on the information published about early repayment programs, the National Asset Management program, the exchange rate debts program, and estimates of forced sales. 
its discourse-setting position, hence they needed to take steps. The solution was a contested decree issued by the Curia according to which unilateral changes in interest rates and the use of different exchange rates was indeed deemed unfair and invalidated contracts. This took the wind out of the sails of social movements. Serious change was brought about by the conversion of FX loans to HUF loans, even though leading experts in the National Bank thought this solution problematic. ${ }^{13}$

Banks survived these years in a weakened political position, although by increasing service fees they could compensate for some of their losses. With restructured loans and the sale of pending claims they could rid themselves of political responsibility and prepare for a new period as creditors.

\subsection{Household responses to the credit crunch}

The difficulties households ran into paying their instalments after the beginning of the 2008 crisis were usually a result of one or more of the following factors: s worsening labor market position (I11, I12, I13, I14, I16, I19, I22), or individual-level issues like unexpected healthcare costs (I10, I22) or deteriorating family relationships, divorce, etc. (I21). Controversial and hesitant government reactions worsened their plight, as even households that sought to make rational calculations could not keep up with the changing landscape of options (I6, I13). Elsewhere, in countries with comparable FX loan problems, swift action helped households adapt (Bohle, 2014, Erbenova et al. 2011). Households often delayed decisions (I5, I19), hoping for better programs, not willing to let go of their homes, or not acknowledging the severity of problems soon enough (I14). Delays or not, hastily made decisions sometimes resulted in such imbalances that households went bankrupt (I7, I12, I15, I16).

Hence, not only strategies per se but timing was also crucial in successfully managing the crisis. Households needed to move beyond the myth that private home ownership was the only viable, safe option (I11, I16). Successful adaptation hinged on quickly making new assessments and identifying rescue programs that offered affordable solutions. Many families acknowledged their own fault in not assessing risks well initially (I13), but later shifted to blaming banks and the government (I8) (Szabó 2018).

For many, interventions suggested they would be "rescued" and many felt entitled to external help. To a large extent, these false hopes contributed to

13 Cf. Balás and Nagy 2010, and statements made by National Bank director György Matolcsy and Mihály Varga from the Ministry of National Development in 2012. 
households getting stuck in crises, as they did not realize early enough that without taking steps they might end up in a significantly worse housing position than they started with (I5, I11); often, they did not accept the reality of overindebtedness and its implications for their social status and ended up stuck in homes not appropriate for their family or career situation (I13, I16). The promise of upward mobility many bought into with foreign-currency loans often led to socio-economic disintegration eventually.

While the impact of decreasing wages and growing monthly instalments was obvious, families could exercise various kinds of influence. The literature on welfare systems usually considers the role of family and friends as unequivocally positive (Ferrera 1996); families are thought to temper inequalities and increase the resilience of households. However, close ties often increase risks during crises, the consequences of which are borne by the broader family: taking out mortgages using family members' homes as collateral and informal lending practices often worsen households' positions, rather than helping (I10, I22, I32).

Individual stories illustrate housing strategies, including stories about taking mortgages and running into difficulty with repayments. Responses to events can be clustered, and these amount to typical strategies. In the qualitative part of our research we focused on those households for whom private home ownership would have been unimaginable without a mortgage and/or those who did not have the savings required to pay for a larger or a better located home. Higher consumption levels were made possible by loans for these people, but it was exactly the latter whose position in the labor market or in terms of family networks was usually less stable (I4, I14, I16).

Many were single-earner households in which incomes were often only partly declared or unstable; the former were more susceptible to crises as a loss of employment, health problems, etc. could dramatically destabilize their strategies. Since they often struggled financially, many of these earners took up work abroad, usually illegally, to be able to pay for the increase in instalments. This financial and emotional pressure often contributed to the dissolution of families. Extended families sometimes tempered these tendencies by offering temporary shelter, or chipping in with repayments, risking their own financial stability. Equally often, they were not able to help, or even added to problems by informal borrowing, etc.

Reactions to growing instalments and the deepening crisis may be grouped into six main categories:

1. Adaptation for the purpose of maintaining a mortgage: return to the parental home, renting out property (I18)

A significant way out of trouble was intergenerational cohabitation, allowing the renting out of the real estate in question in order to cover 
growing instalments. Those families chose this strategy that were not able to keep up with payments but still wanted to hold onto property, and who normally came from more or less stable backgrounds they could rely on. Early repayment was not an option for them. This strategy was usually sustainable, if not ideal.

2. Adaptation for the purpose of maintaining a mortgage: working abroad, emigration (I21,I31)

Those with a relatively stable position on the Hungarian labor market could cope with monthly payments, but many were not able to keep up with growing instalments. The higher wages earned abroad allowed them to obtain the resources needed to service their contracts. With this strategy, many families were able to consolidate their housing situation, or even improve it, though often at the cost of compromised living standards abroad, at least temporarily.

3. Adaptation for the purpose of maintaining a mortgage: sacrificing savings, pensions, etc. in order to keep the home as collateral (I7,I8,I9,I10,I12,I17,I 22,I28,I29)

Many chose to hold onto homes acquired with much difficulty, undertaking sacrifices by cutting their consumption drastically, relying on informal loans, or using insurance or pension funds for repayments. Money from inheritance and selling valuables such as cars could support these strategies. Housing mobility was potentially severely compromised by this strategy, often for decades, and life quality was compromised. It was more common for younger people to avoid this strategy as they often saw more potential for regaining assets in the future.

4. Default: loss of collateral, renting, or compromised housing alternatives (I5,I14,I15, I19,I26, I33)

This strategy was premised upon the loss of the collateral home, which was most often the family home itself, but occasionally it involved other family members' homes, especially those of parents and siblings. This endangered the stability of the extended family, while parental help was insufficient in many such cases, pushing these families to rent or use the remainder of their assets (usually after a forced sale) to move into a home of worse quality and/or location.

5. Default: loss of collateral, return to the parental home (I4,I16,30)

When the loss of a collateral-based home did not come with the erosion of family ties, parents often guaranteed housing stability through intergenerational arrangements, compromising their own comfort. Debtors often returned at a various stages of the life-cycle, with children, resulting in crowded housing conditions. 
6. National Asset Management Ltd.: opting for social housing programs (I32,I39)

NAM allowed debtors to stay in their property, giving them the right to purchase it back within five years. Only a small fraction of individuals were able to do so, even though rising real estate prices after 2015 indicated the economic benefits of this strategy. Flats in Ócsa that were managed by NAM were given to families who had already lost their homes and who had been forced to rent. $10-15 \%$ of tenants accumulated debt, not having paid the low rents. These families were made part of a comprehensive social mentoring program managed by the social services of the Calvinist Church or the Charity Service of the Order of Malta. For many families in these programs, borrowing was a desperate and unrealistic step, thus the stable conditions offered by NAM were a considerable improvement.

The above-described alternatives meant that uncertain housing situation returns and suboptimal housing conditions remained the only option for many. These marginal positions are exactly what so many families tried to break out from through obtaining mortgages in the first place.

\section{CONCLUSIONS}

Housing policy that responded to the shortcomings characteristic of postsocialist housing regimes in Hungary aimed to strengthen both the social and the private rental sector. In addition, there was an attempt to develop an affordable market housing system around the turn of the millennium. Both the expansion of the mortgage market, and especially the rapid spread of FX loan lending, reinforced the already dominant aspect of the housing regime: i.e. market-integrated private home ownership.

The 2008 crisis fundamentally changed this. FX loans generated losses and the cost of this needed to be distributed. Both creditors and debtors had a vested interest in avoiding responsibility. State intervention came in the form of several programs that attempted to alleviate social and economic costs, offering a moment to rethink the housing system as a whole, and foster change. However, the responses and adaptive strategies of institutions, interest groups as well as households yet again reinforced the problematic elements of the housing regime, perpetuating the key issues that preceded the economic crisis in 2008. By the time the housing market recovered in 2015, private home ownership was again reinforced as the cornerstone of housing policy, heavily relying on a better 
fiscal background supported by EU subsidies and economic consolidation. The largest social housing program is now being dissolved, with no real prospect of substantial changes in public housing. This return to the former model misses the chance to correct the housing regime by building on the experiences of the past 15 years, thereby risking a comparable crisis in the future.

\section{REFERENCES}

Ando, A., and F. Modigliani (1957), "Tests of the life-cycle hypothesis of savings: Comments and suggestions", Bulletin of the Oxford Institute of Statistics vol. 19, pp. 99-124.

Ball, M. és M. Harloe (1992) „Rhetorical barriers to understanding housing provision: What the 'provision thesis' is and is not." Housing Studies, 7(1): 3-15.

Barlow, J. and Duncan, S. (1988) The use and abuse of the housing tenure Housing Studies, Vol 3 No 4 pp. 219-331

Barrell, R., Davis, E.F., Fic, F. and Orazgani, A. (2009) „Household Debt and Foreign Currency Borrowing in New Member States of the EU." Working Paper No. 09-23, Brunell University West London, Department of Economics and Finance

Beck, Ulrich (1992) Risk Society: Towards a New Modernity. New Delhi: Sage. Bethlendi András (2009) „A hazai hitelpiac empirikus vizsgálata fejlődési irányok, makrogazdasági és pénzügyi stabilitási következmények.” Ph.D. értekezés, Budapest University of Technology and Economics. https:// repozitorium.omikk.bme.hu/bitstream/handle/10890/782/ertekezes. pdf?sequence $=1$ [Empirical analysis of the Hungarian loan market: development trajectories, consequences the macroeconomy and financial stability; PhD dissertation]

Bohle, Dorothee (2014) "Post-Socialist Housing Meets Transnational Finance: Foreign Banks, Mortgage Lending, and the Privatization of Welfare in Hungary and Estonia." Review of International Political Economy, 21(4): 913-48.

Bohle, D. (2018) Mortgaging Europe's Periphery in: Studies in Comparative International Development June 2018, Volume 53, Issue_2, pp 196-217

Csillag István és Mihályi Péter (2011) „Tizenkét érv a devizahitelesek megmentése ellen.” Népszabadság, május 14 [Twelve arguments against rescuing FX-debtors]

Clapham, David (2005) The meaning of housing: a pathways approach. Bristol, UK: Policy Press 
Clapham, David (2002) „Housing Pathways: A Post Modern Analytical Framework". Housing, Theory and Society 19(2): 57-68. https://doi. org/10.1080/140360902760385565.

Csizmady A. and Hegedüs J. (2016) „Hungarian Mortgage Rescue Programs 2009-2016." NBP Working Paper No. 243 The Narodowy Bank Polski Workshop: Recent trends in the real estate market and its analysis - 2015 edition Volume 1 Economic Institute Warsaw, 11-34.

Dancsik Bálint, Fábián Gergely, Fellner Zita, Horváth Gábor, Lang Péter, Nagy Gábor, Oláh Zsolt, Winkler Sándor (2015) „A nemteljesítő lakossági jelzáloghitel-portfólió átfogó elemzése." MNB-tanulmányok különszám, 2015 [Analyzing the mortgage-portfolio of non-compliant debtors]

Doling, J. and Ronald, R. (2010) „Home ownership and asset-based welfare.” Journal of Housing and the Built Environment, 25(2): 165-173.

Dömötör, Barbara (2011): A kockázat megjelenése a származtatott pénzügyi termékekben. Hitelintézeti Szemle 11: 360-369. [The risk appearing in financial derivatives]

Erbenova, M., Liu, Y. and Saxegaard, M. (2011) „Corporate and Household Debt Distress inLatvia: Strengthening the Incentives for a Market-Based Approach to Debt Resolution." IMF Working Paper

Ferrera M. (1996) „The 'southern model' of welfare in social Europe..” Journal of European Social Policy, 6(1): 17-37.

Fitzpatrick, Suzanne and Mark Stephens (2014) „Welfare Regimes, Social Values and Homelessness: Comparing Responses to Marginalised Groups in Six European Countries." Housing Studies 29(2): 215-34.

Gáspár K. and Varga Zs. (2011) „A bajban lévő lakáshitelesek elemzése mikroszimulációs modellezéssel." Közgazdasági szemle, 58(6): 529-542. [Analyzing indebted borrowers' situation with microsimulation]

Gazdasági Minisztérium (2000) Széchenyi Terv. Lakásprogram. Gazdasági Minisztérium: Budapest, 2000. December [Széchenyi Plan. Housing program] Giddens, Anthony (1999) Runaway World: How Globalization is Reshaping Our Lives. London: Profile

Haffner, Marietta, Joris Hoekstra, Michael Oxley and Harry Van Der Heijden (eds.) (2009) „Bridging the Gap between Social and Market Rented Housing in Six European Countries?" Housing and Urban Policy Studies 33. Amsterdam: IOS Press Hegedüs, J., Mayo, S. and Tosics I. (1996) „Transition of the Housing Sector in the East Central European Countries." Review of Urban \& Regional Development Studies 8(2): 101-136. DOI: 10.1111/j.1467-940X.1996.tb00113.x Hegedüs, J. and Tosics I. (1996) „Disintegration of East-European Housing Model." in: Clapham, D., Hegedüs, J., Kintrea, K. and I. Tosics (eds.) Housing Privatization in Eastern Europe, Greenwood, 15-39. 
Hegedüs J. and Szemző H. (2015) „The Role of Housing Assets in Shaping the New Welfare Regime in Transition Countries: The Case of Hungary." In: Critical Housing Analysis, 2(1): 82-90.

Hegedüs J. and Teller N. (2007) „Hungary: Escape into homeownership.” In: Elsinga M; Decker P; Teller N and Toussaint J. (eds.) Homeownership beyond asset and security. Housing and Urban Policy Studies, 32. Amsterdam: IOS Press. 133-172.

Hegedüs József (2006) „Lakáspolitika és a lakáspiac - a közpolitika korlátai.” Esély, 17(5): 65-100. [Housing politics and the housing market: the limits of public policy]

Hegedüs József (2011) „Housing policy and the economic crisis - the case of Hungary." in: Ray Forrest and Ngai-Ming Yip (eds.) Housing Markets and The Global Financial Crisis: The Uneven Impact On Households. Cheltenham: Edward Elgar Publishing Limited. 113-130.

Hegedüs, J., V. Horváth and E. Somogyi (2014) „,The Potential of Social Rental Agencies within Social Housing Provision in Post-Socialist Countries: The Case of Hungary." European Journal of Homelessness, 8(2): 41-67.

Hegedüs József (2018) „Lakásrezsimek rendszerváltás előtt és után a posztszocialista államokban.” in: Bozóki András és Füzér Katalin (szerk.) Lépték és irónia : Szociológiai kalandozások. 73-125. Budapest: MTA Társadalomtudományi Kutatóközpont [Housing regimes before and after the regime change in post-socialist countries]

Hegedüs József and Raymond Struyk (2005) „Divergences and Convergences in Restructuring Housing Finance in Transition Countries." in: Hegedüs, J. and Struyk, R.J. (ed.) Housing Finance: New and Old Models in Central Europe, Russia and Kazakhstan. LGI Books, Open Society Institute, 3-41.

Hojsik, M. (2013) „Slovakia: On the way to a stable social housing concept.” in: Hegedüs, Lux, Teller (eds.) Social Housing in Transitional Countries, 262-277. Kemeny, J. (1995) From Public Housing to the Social Market: Rental Policy Strategies in Comparative Perspective. London: Routledge.

Kemeny, J., J. Kersloot and P. Thalman (2005) „Non-profit housing, influencing, leading and dominating the unitary rental market: three case studies." Housing Studies, 20(6): 855-872.

Kemeny, J and Lowe, S (1998) „Schools of comparative housing research: from convergence to divergence ${ }^{\text {ee }}$ Housing Studies, 13(2): 161-176.

Király, J. (2016): Az amerikai másodrendü jelzálogpiaci és a magyar devizahitelválság összehasonlító elemzése in: Simonovits 70 (szerk.: Gál Róbert és Király Júlia) Budapest MTA KRTK 2016, 326-350 [A comparative analysis of the crises of the US secondary mortgage and the Hungarian mortgage market] KSH (1989) Családi Költségvetés, 1987. KSH Budapest. [Family budgets] 
KSH (2015) Housing survey 2015. KSH. Budapest

KSH (2011) A hitellel rendelkező háztartások szociális jellemzői. Available at: http://www.ksh.hu/docs/hun/xftp/stattukor/hitelesekszocjell.pdf [Social charactersitics of households with loans]

Le Grand, J. (2003) Motivation, agency, and public policy of knights and knaves, pawns and queens. Oxford : Oxford University Press, 2003.

Lin, Justin Yifu (2012) New Structural Economics: A Framework for Rethinking Development and Industrial Policy. Washington, DC: World Bank.

Lowe, Stuart (2003) „Housing in post-communist Europe - Issues and agenda.” in: Lowe and Tsenkova (eds.) Housing Change in East and Central Europe: Integration or Fragmentation. Aldershot: Ashgate, 21-44. ISBN: 0754618145, 9780754618140

Lundqvist, Lennart J. (1990) „Rolling Stones for the Resurrection of Policy as the Focus of Comparative Housing Research." Paper presented at the International Housing Conference Housing Debates - Urban Challenges', Paris, 3-6 July

Malpass, Peter (2008) „Housing and the New Welfare State: Wobbly Pillar or Cornerstone?" Housing Studies, 23(1): 1-19.

Matznetter, Walter (2002) „Social Housing Policy in a Conservative Welfare State: Austria as an Example." Urban Studies 39(2): 265-82.

Matznetter, Walter and Alexis Mundt (2012) „Housing and Welfare Regimes.” in The SAGE Handbook of Housing Studies, 274-94. London: Sage Publications Medgyesi Márton (2008) „Jut is? Marad is? A háztartások megtakarításai.” in: Szivós Péter and Tóth István György (szerk.) Köz, teher, elosztás Tárki Monitor Jelentések, 155-173. [Household savings: enough and to spare?]

MNB (2010) Jelentés a pénzügyi stabilitásról, 2010 április [Report on financial stability, April 2010]

Növekedéskutató Intézet (1999) Reális Lakáspolitika. Available at: http://www. lakasepitesert.hu/upload/1999\%20Re\%C3\%A1lis\%20lak\%C3\%A1spolitika. pdf [Realisting housing politics]

Oblath Gábor (2010) „Ki, miben felelös? Észrevételek Surányi György diagnózis- és terápia-kritikájához." KTI blog. Available at: http://blog.mtakti. hu/blog_cikkek/index.php?leftmenuid[leftmenuid]=5\&cikk_listazo[pager] [pg] $=240$ [Who is responsible for what? On György Surányi’s crititcisms of dignosis and therapy]

OGY (2012) Az Országgyülés Alkotmányügyi, igazságügyi és ügyrendi bizottságának jelentése a 2002-2010. közötti lakossági deviza-eladósodás okainak feltárásáról, valamintazesetleges kormányzati felelösség vizsgálatáról. 2012 február. Available at: http://www.parlament.hu/irom39/05881/05881. pdf [Report on the reasons of FX-indebtedness and an analysis of potential 
governmental responsibility by the Parliament's Constitutional, Judicial and Procedural Committee]

O'Malley, Pat (2004) Risk, uncertainty and government. London: Glasshouse Press.

Otthon Európában (2003) Otthon Európában - A nemzeti lakásprogram pillérei. Budapest, 2003 Nozeti Lakásprogram Iroda, 2003 [At home in Europe Pillars of the national housing program]

Pavlovskaya, M. (2004) „Other transitions: multiple economies of Moscow households in the 1990s." Annals of the Association of American Geographers, 94(2): 329-351.

Pete Péter (2010) „Felelős.” Magyar Narancs 2010/7 Available at: http:// magyarnarancs.hu/egotripp/felelos-73196 [Responsible]

Pichler-Milanovich, Natasha (2001) „Urban housing markets in central and eastern Europe: Convergence, divergence or policy collapse." European Journal of Housing Policy 1(2):145-187

PSZÁF (2012) Gyorselemzés a végtörlesztésröl. Pénzügyi Szervezetek Állami Felügyelete, 2012 https://www.mnb.hu/letoltes/gyorselemzes-vegtorlesztes120312j.pdf [A quick assessment of the early repayment program]

Ries, Nancy (1997) Russian Talk: Culture and Conversation during Perestroika. Ithaca, NY: Cornell University Press

Róna Péter (2013) „Hibás termék.” Magyar Nemzet, 2013 augusztus 8. http:// balazs.pergamen.hu/downloads/hibas_termek.pdf [Faulty product]

Roy, F (2008) „Mortgage Markets in Central and Eastern Europe - a review of past experiences and future perspectivese ${ }^{\text {ee }}$ European Journal of Housing Policy, 8(2): 133-160

Schepp, Zoltán (2008): Néhány gondolat a változó kamatozású devizafinanszírozás kockázatairól. Hitelintézeti Szemle, 1, 67-90.

Small, Mario Luis (2009): "How many cases do I need?": On science and the logic of the case selection in the field based research, Ethnography 2009/10, 5-35

Stephens, Mark, Martin Lux and Petr Sunega (2015) „Post-Socialist Housing Systems in Europe: Housing Welfare Regimes by Default?" Housing Studies 30(8): 1210-34. https://doi.org/10.1080/02673037.2015.1013090

Surányi Gy. (2010) „Téves diagnózis, téves terápia.” Népszabadság, 2010, január $30 \mathrm{http} / / / \mathrm{nol} . \mathrm{hu} / \mathrm{gazdasag} / \mathrm{teves}$ _diagnozis_teves_terapia-525601 [False diagnosis, false therapy]

Surányi György (2015) „A jegybank mindenben hibázott, amiben lehetett.” Origo, 2015.2.24 http://www.origo.hu/gazdasag/20150223-suranyi-gyorgy-ajegybank-mindenben-hibazott-amiben-lehetett.html [The reserve bank made all possible mistakes] 
Szabó, Natasa (2018) „We are the State, We are the People: Forex Loan Debtors' Struggles for Citizenship in Hungary." MA thesis at Central European University, Department of Sociology and Social Anthropology

Székely, Gáborné (2011) Társadalmi helyzetkép 2010. Lakáshelyzet. [Social state of play 10. Housing conditions], HCSO, Budapest, 2011.

Szőke, A. (2015). A 'Road to Work'? The reworking of deservedness, social citizenship and public work programmes in rural Hungary. Citizenship Studies, 19(6-7), 734-750.

Tsenkova, Sasha (2009) Housing Policy Reforms in Post Socialist Europe: Lost in Transition. Springer

Tóth, I. János, and Árvai Zsófia (2001) „Likviditási korlát és fogyasztói türelmetlenség. A magyar háztartások fogyasztási és megtakarítási döntéseinek empirikus vizsgálata.” Közgazdasági Szemle XLVIII.(12): 1009_ 38. [Liquidity limits and consumer inpatience. An empirical analysis of

Várhegyi Éva (2002) „Polgári Otthon.” Magyar Narancs 2002/11 Available at: https://magyarnarancs.hu/egotripp/varhegyi_eva_ekotrip-55652 [Middle Class Home]

Várhegyi Éva (2010) „Hitelek fogságában.” Élet és Irodalom, LXII. 42. Available at: https://www.es.hu/cikk/2010-10-2/varhegyi-eva/hitelek-fogsagaban.html [Caught in loans]

Várhegyi Éva (2018) „Bankcsapda.” Magyar Narancs, 2018/8 2018.2.2. http:// magyarnarancs.hu/publicisztika/bankcsapda-109480 [Bank-trap]

Zsoldos István (1997) „A lakosság megtakarítási és portfólió döntései Magyarországon 1980-1996 között.” MNB Füzetek, 1997/4 [Individual saving and portfolio decisions in Hungary, 1980-1996] 


\section{APPENDIX: LIST OF STRUCTURED INTERVIEWS}

\begin{tabular}{|c|c|c|c|c|c|c|}
\hline Key & Type & Family & $\begin{array}{l}\text { Private } \\
\text { rental }\end{array}$ & $\begin{array}{l}\text { Suboptim } \\
\text { al } \\
\text { circumsta } \\
\text { nces }\end{array}$ & $\begin{array}{l}\text { State } \\
\text { support }\end{array}$ & $\begin{array}{l}\text { FX } \\
\text { loan }\end{array}$ \\
\hline interview_1 & 7 & couple +5 children & yes & yes & yes & no \\
\hline interview_2 & 7 & couple +3 children & yes & yes & yes & no \\
\hline interview_3 & 7 & couple +3 children & yes & yes & yes & yes \\
\hline \begin{tabular}{|l|} 
interview_4 \\
\end{tabular} & 2,3 & couple +4 children & no & yes & no & yes \\
\hline interview_5 & 2 & couple +4 children & yes & yes & yes & yes \\
\hline interview_6 & 7 & couple +3 children & no & no & yes & yes \\
\hline \begin{tabular}{|l|} 
interview_7 \\
\end{tabular} & 4 & couple +3 children & yes & yes & no & yes \\
\hline interview_8 & 4 & pensioner couple & no & yes & no & yes \\
\hline interview_9 & 4 & couple +2 children & yes & no & no & yes \\
\hline interview_10 & 4 & couple & no & yes & no & yes \\
\hline interview_11 & 7 & single & no & yes & no & yes \\
\hline interview_12 & 4 & couple + grandchild & no & yes & no & yes \\
\hline interview_13 & 7 & single & no & yes & no & yes \\
\hline interview_14 & 2 & single & no & yes & yes & no \\
\hline interview_15 & 2 & single & yes & no & no & yes \\
\hline interview_16 & 2,3 & couple +2 children & no & no & no & yes \\
\hline interview_17 & 4 & couple + child & no & yes & no & yes \\
\hline interview_18 & 1 & couple + child & yes & yes & no & yes \\
\hline interview_19 & 2 & couple + child & no & yes & no & yes \\
\hline interview_20 & 7 & couple + child & yes & yes & no & yes \\
\hline interview_21 & 5 & single & yes & yes & no & yes \\
\hline interview_22 & 4 & couple & no & yes & no & yes \\
\hline interview_23 & 7 & single & no & no & yes & no \\
\hline interview_24 & 7 & couple & yes & no & no & yes \\
\hline interview_25 & 7 & couple + children & yes & yes & no & yes \\
\hline interview_26 & 2 & couple & yes & yes & no & yes \\
\hline interview_27 & 7 & divorced + child & no & yes & yes & no \\
\hline interview_28 & 4 & couple +3 children & no & yes & yes & yes \\
\hline interview_29 & 4 & divorced +2 children & no & no & no & yes \\
\hline interview_30 & 8 & divorced + single & no & no & no & yes \\
\hline interview_31 & 5 & couple +4 children & yes & n.a. & n.a. & yes \\
\hline interview_32 & 6 & Couple +8 children & no & yes & yes & \\
\hline interview_33 & 2 & divorced +3 children & no & no & no & yes \\
\hline interview_34 & 6 & Divorced + child & no & no & no & yes \\
\hline interview_35 & 8 & Couple + child & no & no & no & yes \\
\hline
\end{tabular}

Types:

1. Return to parents, rent own flat.

2. Loss of home, new rented home or residual housing.

3. Loss of home, living with family/parents.

4. Keeping home through substantial sacrifices, pooling resources.

5. Work abroad.

6. Social housing - National Asset Management Ltd.

7. No crisis, or was able to buy a new home with family support.

8. Under execution 
